\title{
THE ROLE OF METABOLIC DISORDERS IN THE FORMATION OF UROLITHIASIS IN PATIENTS WITH TYPE 2 DIABETES MELLITUS*
}

\author{
Kolupayev S. M. ${ }^{1,2}$, Andonieva N. M., ${ }^{1,2}$ Kirienko O. M. ${ }^{1}$, Khanzhyn V. V. ${ }^{1}$, Iemets D. O. ${ }^{2}$ \\ ${ }^{1}$ Kharkiv National Medical University, Kharkiv, Ukraine; \\ ${ }^{2}$ Regional Medical Clinical Center of Urology and Nephrology named \\ after V. I. Shapoval, Kharkiv, Ukraine \\ sm_kolupayev@ukr.net
}

Diabetes mellitus (DM) has been and remains one of the urgent problems of modern medicine because of the comorbid syndrome development [1]. In the general structure of comorbidity in patients with type 2 diabetes mellitus, diseases of the urogenital system takes 3rd place after diseases of the nervous and cardiovascular systems [2]. Immune system disorders, inadequate metabolic control of diabetes, incomplete emptying of the bladder due to autonomic neuropathy are pathogenetic factors for the development of urinary tract infections (UTIs) in patients with diabetes [3].

The increased incidence of acute and chronic urinary tract infections, such as pyelonephritis and cystitis, is a common situation for such patients, but an increase in the incidence of urolithiasis is a new trend. The previous studies have shown an increasing prevalence of nephrolithiasis in patients with (DM) compared with patients without diabetes [4].
$10-15$ years ago, it was $0.5-1 \%$, but now various authors give prevalence figures from 6 to $10 \%[5,6]$. There are contradictory opinions about the mechanisms of stone formation in patients with diabetes.

According to various authors, the key factors in the pathogenesis of kidney stones formation in diabetes are excessively acidic urine reaction $[4,7]$, increased concentrations of uric acid and calcium in serum and urine [7], impaired renal parenchymal microcirculation, and insulin resistance [8].

All the above-mentioned makes the study of metabolic disorders in patients with type $2 \mathrm{DM}$ and concomitant urolithiasis relevant to identify possible mechanisms of lithogenesis.

The aim of the study was to examine the role of metabolic disorders in the development of urolithiasis, and to study the characteristics of the mineral composition of urinary stones in patients with type $2 \mathrm{DM}$.

* The work was carried out in accordance with the scientific theme: «Optimization of diagnosis and treatment of cardiovascular disorders in patients with type 2 diabetes mellitus in the conditions of combined pathology» (№ state registration 0118U000950).

Institution, which financed the research: Ministry of Health of Ukraine.

The authors assume responsibility for the published work.

The authors guarantee absence of competing interests and their own financial interest when carrying out the research and writing the article.

The manuscript was received by the editorial staff 16.03.2021. 


\section{MATERIAL AND METHODS}

The study included 28 patients with type 2 diabetes mellitus aged from 47 to 68 years (mean age 52.4 years), including 12 women $(43 \%)$ and 16 men (57\%) who were treated at the Regional Medical Clinical Center of Urology and Nephrology named after V. I. Shapoval (Kharkiv, Ukraine).

Depending on the duration of diabetes, 2 groups of patients were formed. Group 1 consisted of patients with the disease duration up to 8 years (9 men and 6 women); group 2 was represented by patients with DM duration 8 years or more ( 7 men and 6 women). To correct carbohydrate metabolism, the patients received tablet sugar-lowering drugs of the biguanide group.

All patients underwent a comprehensive examination, including an assessment of laboratory parameters: the level of glycated hemoglobin (HbA1), glomerular filtration rate (GFR), serum concentration of triglycerides (TG), urea, creatinine and uric acid, as well as ultrasound examination of the urinary system. If there were stones in the kidneys or urinary tract, the patients underwent contrastenhanced computed tomography on a Toshiba Aquilion 16 multispiral X-ray tomograph (Japan) in order to clarify their localization, size and X-ray density. Depending on the stone parameters, the patients underwent extracorporeal shock wave lithotripsy, contact laser ureterolithotripsy or percutaneous nephrolithotripsy, followed by assessment of the mineral composition of the obtained stone fragments by infrared (IR) spectroscopy using an IKS-29 infrared spectrophotometer (LOMO, Russia).

Before carrying out diagnostic and therapeutic procedures, all patients were informed about the goals, methods and objectives of the study, and then they voluntarily signed an informed consent.

Statistical processing of the data obtained during the study was carried out using Microsoft Excel 2016 spreadsheets and Statistica 10 software (StatSoft, USA). Quantitative values are presented as median (Me) and interquartile range (Q1 and $\mathrm{Q} 3)$, where $\mathrm{Q} 1$ is the $25^{\text {th }}$ percentile, Q3 is the $75^{\text {th }}$ percentile. The Mann-Whitney U-test was used to compare the values in the groups of patients with diabetes mellitus, the differences were considered statistically significant at $p<0.05$. The correlation dependence was determined using Spearman's rank correlation (p). Up to $5 \%$ significance level $(p<0.05)$ was considered statistically significant.

\section{RESULTS AND THEIR DISCUSSION}

When analyzing the biochemical parameters of blood, we found out that all studied patients had hyperuricemia. A positive correlation was found between the level of uric acid in the blood and the duration of diabetes mellitus, both in men $(\mathrm{r}=0.64, \mathrm{p}<0.05)$ and in women $(r=0.58, p<0.05)$, while the concentration of uric acid in the blood did not depend on age $(r=0.27, p>0.05$ for men, $r=0.31, p>0.05$ for women) and the gender of patients $(r=0.35$, $p>0.05$ and $r=0.29, p>0.05)$. The level of uricemia increased simultaneously with the level of creatinine in the blood. At the same time, glomerular filtration varied within wider limits and in some cases, it decreased to rather low values (Table 1 ).

An increase in the serum levels of the uric acid and creatinine may be a consequence of impaired renal excretory capacity, which progresses with the increase of disease duration [4].
The levels of triglycerides and glycosylated hemoglobin in the blood of patients with different duration of diabetes mellitus did not differ significantly.

There was a direct correlation between the concentration of uric acid in the blood and the level of HbA1 ( $r=0.38, p<0.05$ for men, $\mathrm{r}=0.42, \mathrm{p}<0.05$ for women), which is a marker of the degree of carbohydrate metabolism compensation.

In the modern literature, the question of the hyperuricemia dependence on the carbohydrate metabolism compensation is much discussed. A number of authors consider hyperuricemia an independent predictor of type 2 diabetes mellitus [9]. According to the results of some epidemiological studies, their authors suggested that hyperuricemia should be considered, to a greater extent, as an independent risk factor of renal failure development 
Biochemical parameters of patients with type 2 diabetes mellitus with different disease duration, Me [25\%- $75 \%]$

\begin{tabular}{|c|c|c|c|c|}
\hline \multicolumn{2}{|c|}{ Disease duration / Indicator } & $<8$ years & $\geq 8$ years & $\begin{array}{c}\text { Mann-Whitney } \\
\text { U test (p) }\end{array}$ \\
\hline \multirow{2}{*}{ Uric acid, $\mu \mathrm{mol} / \mathrm{l}$} & male & $\begin{array}{c}473.00 \\
{[463.00 ; 483.00]}\end{array}$ & $\begin{array}{c}560.00^{\#} \\
{[542.00 ; 606.00]}\end{array}$ & $<0.001$ \\
\hline & female & $\begin{array}{c}388.00 \\
{[360.25 ; 408.25]}\end{array}$ & $\begin{array}{c}441.00^{\#} \\
{[420.75 ; 467.25]}\end{array}$ & 0.004 \\
\hline \multirow{2}{*}{$\mathrm{GFR}, \mathrm{ml} / \mathrm{min}$} & male & $\begin{array}{c}90.35 \\
{[89.32 ; 94.35]} \\
\end{array}$ & $\begin{array}{c}65.82^{\#} \\
{[55.18 ; 73.86]} \\
\end{array}$ & 0.003 \\
\hline & female & $\begin{array}{c}88.87 \\
{[86.74 ; 90.58]}\end{array}$ & $\begin{array}{c}66.94^{\#} \\
{[58.83 ; 77.97]}\end{array}$ & 0.02 \\
\hline \multirow{2}{*}{$\mathrm{HbA} 1, \%$} & male & $\begin{array}{c}9.50 \\
{[8.60 ; 10.80]}\end{array}$ & $\begin{array}{c}11.70 \\
{[9.70 ; 12.35]}\end{array}$ & 0.11 \\
\hline & female & $\begin{array}{c}8.10 \\
{[7.95 ; 9.60]}\end{array}$ & $\begin{array}{c}11.45 \\
{[10.43 ; 13.15]}\end{array}$ & 0.24 \\
\hline \multirow{2}{*}{$\mathrm{TG}, \mu \mathrm{mol} / \mathrm{L}$} & male & $\begin{array}{c}1.95 \\
{[1.82 ; 2.11]}\end{array}$ & $\begin{array}{c}2.14 \\
{[1.73 ; 2.54]}\end{array}$ & 0.84 \\
\hline & female & $\begin{array}{c}1.81 \\
{[1.74 ; 1.86]}\end{array}$ & $\begin{array}{c}2.19 \\
{[1.93 ; 2.33]}\end{array}$ & 0.24 \\
\hline \multirow{2}{*}{$\begin{array}{c}\text { Creatinine, } \mu \mathrm{mol} \\
\text { / L }\end{array}$} & male & $\begin{array}{c}98.7 \\
{[92.40 ; 108.40]}\end{array}$ & $\begin{array}{c}150.40^{\#} \\
{[141.15 ; 166.55]}\end{array}$ & 0.002 \\
\hline & female & $\begin{array}{c}84.85 \\
{[82.05 ; 91.63]}\end{array}$ & $\begin{array}{c}133.95^{\#} \\
{[129.50 ; 146.88]}\end{array}$ & 0.002 \\
\hline
\end{tabular}

Note:

\# significant differences with the group of patients with DM duration less than 8 years at $p<0.05$ according to the Mann-Whitney test.

and progression, rather than an indicator of compensation for carbohydrate metabolism [10]. With intact renal function, hyperproduction of uric acid characteristic for DM, is usually compensated by hyperuricosuria. As the kidneys get damaged, the "urate-eliminating" function of the kidneys begins to suffer, and the uricosuric stage of increased uric acid production is replaced by the hyperuricemic one. Hyperglycemia, glucosuria that are typical for DM, have a pronounced uricosuric and hypouricemic effect through the blockade of tubular reabsorption of uric acid. This means that hyperuricemia in manifested forms of DM is a phenomenon of a different order than high uric acid concentration in the blood at preclinical stages of diabetes [11].

In our study, urolithiasis as a concomitant disease was detected in $19(67.8 \%)$ of the examined patients. $14(73.7 \%)$ patients had kidney stones and $5(26,3 \%)$ patients had ureter stones. There was a significant increase in the number of patients with stones in the urinary system organs with the longer duration of diabetes mellitus $(r=0.64, p<0.05)$.

The infrared spectroscopy of the mineral composition of removed stone fragments revealed a monophasic composition of stones in $13(68.4 \%)$ patients. The monophasic composition was represented by uric acid or uric acid dihydrate in a crystalline or amorphous state (Fig. 1).

In $6(31,6 \%)$ cases, the stones had a mixed mineral composition, while the dominant component, occupying more than $50 \%$ of the sample volume, was uric acid (Table 2).

There is a supposition that insulin resistance and hyperinsulinemia are the main links of the pathogenesis of metabolic syndrome in the increased acidity of urine and the formation of uric acid stones [8]. The relationship between urine acidification and insulin resistance is also supported by other studies. Abate N. et al. in a study on patients with uric acid stones and 


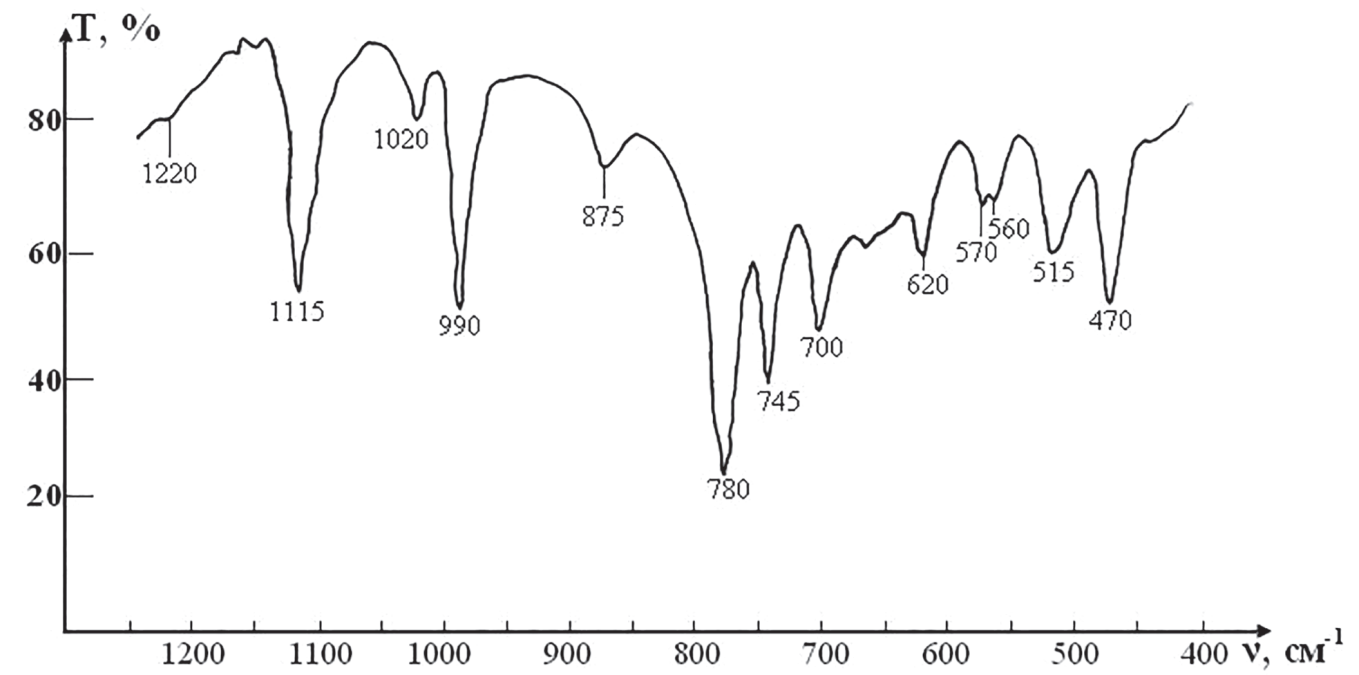

Fig. 1. IR spectrum of kidney stone in the range 1200-400cm-1: absorption bands 1220, 1115, $1020,990,875,780,745,700,620,570,560,515,400$ correspond to crystalline uric acid.

Mineral composition of kidney stones in patients

Table 2 with type 2 diabetes with concomitant urolithiasis

\begin{tabular}{c|c}
\hline Mineral composition of the stone & $\begin{array}{c}\text { Number of samples } \\
\mathbf{n}(\mathbf{\%})\end{array}$ \\
\hline Uric acid & $11(57.9 \%)$ \\
\hline Uric acid dihydrate & $2(10.5 \%)$ \\
\hline Uric acid + Wevellite & $3(15.8 \%)$ \\
\hline Uric acid + Calcium carbonate & $1(5.2 \%)$ \\
\hline Uric acid + Wevellite + Hydroxylapatite & $2(10.5 \%)$ \\
\hline
\end{tabular}

healthy volunteers with the introduction of controlled doses of insulin with an appropriate diet observed a decrease in urine $\mathrm{pH}$, a decrease in the excretion of ammonium ions and citrates, and an increase in the excretion of acids in the urine of patients with uric acid nephrolithiasis compared with the norm [9].

\section{CONCLUSIONS}

The key factor in the development of urolithiasis in patients with type 2 diabetes mellitus is uric acid metabolism disorders. It is manifested by an increase in the level of uricemia with the disease duration progression regardless of the patients' age and gender. The dominant components of urinary stones in patients with type 2 diabetes mellitus are uric acid, as well as uric acid dihydrate in a crystalline or amorphous state.

\section{REFERENCES}

1. Du Y, Heidemann C, Gowald A, et al. BMC Public Health 2013; 13: 166. https://doi.org/10.1186/1471-245813-166.

2. Melihova SP, Shevcova VI, Zujkova AA, Kotova JuA. Arhiv Vnutrennej Mediciny 2018; 8(5): 366-371. https:// doi.org/10.20514/2226-6704-2018-0-5-366-371

3. Nitzan O, Elias M, Chazan B, Saliba W. Diabetes Metab Syndr Obes 2015; 8: 129-136.

4. Nerli R, Jali M, Guntaka AK, et al. Adv Biomed Res 2015; 4: 180. https://doi.org/10.4103/2277-9175.164012.
5. Chao CT, Wang J, Huang JW, et al. BMJ Open Diabetes Res Care 2020; 8(1): e000755. https://doi.org/10.1136/ bmjdrc-2019-000755.

6. Liu LH, Kang R, He J, et al. Urolithiasis 2015; 43: 293301. https://doi.org/10.1007/s00240-015-0773-5.

7. Prosjannikov MJu, Janenko JeK, Jarovoj SK, et al. Urologija 2019; 1: 28-34.

8. Tjuzikov IA. Saharnyj Diabet 2014; 17(1): 47-56. https:// doi.org/10.14341/DM2014147-56. 
9. Chernyaeva AO, Mykytyuk MR, Karachentsev YuI, et al. Problems of Endocrine Pathology 2020; 3: 89-97.

10. Kang DH, Chen W. Semin Nephrol 2011; 31(5): 447-452. https://doi.org/10.1016/j.semnephrol.2011.08.009.

11. Madjanov IV. Medicinskoe Obozrenie 2019; 1(I): 20-24.
12. Maalouf NM, Cameron MA, Moe OW, et al. Clin J Am Soc Nephrol 2007; 9: 883-888.

13. Abate N, Chandalia M, Cabo-Chan AV, et al. Kidney Int 2004; 65: 386-392. https://doi.org/10.1111/j.15231755.2004.00386.x.

\author{
THE ROLE OF METABOLIC DISORDERS \\ IN THE FORMATION OF UROLITHIASIS \\ IN PATIENTS WITH TYPE 2 DIABETES MELLITUS \\ Kolupayev S. M. ${ }^{1,2}$, Andonieva N. M. ${ }^{1,2}$, Kirienko O. M. ${ }^{1}$, \\ Khanzhyn V. V. ${ }^{1}$, Iemets D. O. $^{2}$ \\ ${ }^{1}$ Kharkiv National Medical University, Kharkiv, Ukraine; \\ ${ }^{2}$ Regional Medical Clinical Center of Urology and Nephrology named after V. I. Shapoval, \\ Kharkiv, Ukraine \\ sm_kolupayev@ukr.net
}

The article presents the study of the influence of type 2 diabetes mellitus on the features of the urolithiasis development and factors affecting stone formation. As part of the study, 28 patients with type 2 diabetes mellitus were treated at the «Regional Medical Clinical Center of Urology and Nephrology named after V. I. Shapoval», where a comprehensive examination was carried out to determine the level of glycosylated hemoglobin, glomerular filtration rate, serum concentration of triglycerides, urea, creatinine and uric acid.

All patients underwent ultrasound examination of the urinary system organs. In case of detecting stones in the kidneys or urinary tract, multispiral computed tomography with contrast was performed, which evaluated the size, localization and X-ray density of the stones. Depending on the above parameters, patients underwent extracorporeal shock wave lithotripsy, contact laser ureterolithotripsy or percutaneous nephrolithotripsy, followed by assessment of the mineral composition of the obtained stone fragments by infrared spectroscopy.

The study revealed a positive correlation between the level of uric acid in the blood and the duration of diabetes mellitus both in men $(r=0.64, p<0.05)$ and in women $(r=0.58, p<0.05)$, while the concentration of uric acid in the blood did not depend on the age and gender of the patients. There was a direct relationship between hyperuricemia and the concentration of glycosylated hemoglobin. The level of uricemia increased simultaneously with the level of creatinine in the blood.

Urolithiasis was diagnosed in $67.8 \%$ of the examined patients. There was a significant increase in the number of cases of urolithiasis with an increase in the duration of diabetes mellitus $(r=0.64, p<0.05)$. In $68.4 \%$ of patients, stones had a monophasic composition, which was represented by uric acid or uric acid dihydrate. In $31.5 \%$ of cases, stones had a mixed mineral composition, with uric acid being the dominant component, occupying more than $50 \%$ of the sample volume.

Key words: diabetes mellitus, urolithiasis, hyperuricemia. 


\section{РОЛЬ МЕТАБОЛІЧНИХ ПОРУШЕНЬ \\ У ФОРМУВАННІ СЕЧОКАМ'ЯНОÏ ХВОРОБИ \\ У ХВОРИХ НА ЦУКРОВИЙ ДІАБЕТ 2 ТИПУ}

Колупаев С. М. ${ }^{1,2}$, Андон'ева Н. М., ${ }^{1,2}$, Кіріенко О. М. ${ }^{1}$, Ханжин В. В. ${ }^{1}$, Смець Д. О. ${ }^{2}$

${ }^{1}$ Харьківський національний медичний університет, м. Харків, Украйна;

${ }^{2}$ Обласний медичний клінічний иентр урології і небрологї ім. В. І. Шаповала, Харків, Україна

sm_kolupayev@ukr.net

Стаття присвячена вивченню впливу цукрового діабету 2 типу на особливості розвитку сечокам'яної хвороби і факторів, що впливають на каменеутворення. В рамках дослідження 28 паціентам з цукровим діабетом 2 типу, які перебували на лікуванні в Обласному медичному клінічному центрі урології і нефрології ім. В. І. Шаповала (Харків, Україна), проведено комплексне обстеження з визначенням рівня глікозильованого гемоглобіну, швидкості клубочкової фрільтрації, сироваткової концентрації тригліцеридів, сечовини, креатиніну та сечової кислоти. Всім хворим проводилося ультразвукове дослідження органів сечовидільної системи, за результатами якого, в разі виявлення конкрементів в нирках або сечовивідних шляхах, виконувалася мультиспіральна комп'ютерна томографія 3 контрастуванням, на підставі якої оцінювалися розміри, локалізація і рентгенівська щільність конкременту. Залежно від вищевказаних параметрів, пацієнтам проводилася екстракорпоральна ударно-хвильова літотрипсія, контактна лазерна уретеролітотріпсія або перкутанная нефролітотрипсія з подальшою оцінкою мінерального складу отриманих фррагментів каменю методом інфрачервоної спектроскопії.

В ході дослідження було виявлено позитивну кореляційну залежність між показником рівня сечової кислоти в крові і тривалістю цукрового діабету як у чоловіків $(\mathrm{r}=0,64, \mathrm{p}<0,05)$, так і у жінок $(\mathrm{r}=0,58, \mathrm{p}<0,05)$, при цьому концентрація сечової кислоти в крові не залежала від віку і статі пацієнтів. Була виявлена пряма залежність гиперурикемії від концентрації глікозильованого гемоглобіну. У міру наростання рівня урикемії збільшувався також рівень креатиніну в крові.

У $67,8 \%$ обстежених була виявлена сечокам'яна хвороба. Зазначалося достовірне збільшення числа випадків уролітіазу при збільшенні тривалості цукрового діабету $(\mathrm{r}=0,64, \mathrm{p}<0,05)$. У 68,4\% хворих камені мали монофазний склад, який був представлений сечовий кислотою або дигідратом сечової кислоти. У 31,5 \% випадках камені мали змішаний мінеральний склад, при цьому домінуючим компонентом, що займав більше 50 \% об. зразка, була сечова кислота.

Кл ючові слов а : цукровий діабет, сечокам'яна хвороба, гіперурикемія. 